Supplement of Atmos. Chem. Phys., 20, 771-786, 2020

https://doi.org/10.5194/acp-20-771-2020-supplement

(C) Author(s) 2020. This work is distributed under

the Creative Commons Attribution 4.0 License.

(c) (1)

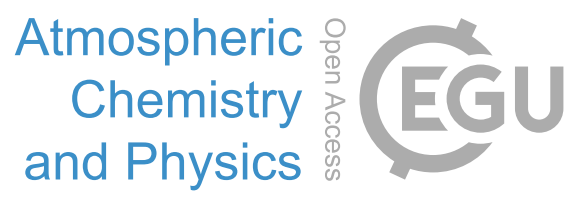

Supplement of

\title{
Natural sea-salt emissions moderate the climate forcing of anthropogenic nitrate
}

\section{Ying Chen et al.}

Correspondence to: Yafang Cheng (yafang.cheng@mpic.de) and Ying Chen (chen@tropos.de)

The copyright of individual parts of the supplement might differ from the CC BY 4.0 License. 


\section{$1 \quad$ Section S1. Modelling of particulate nitrate in global models}

Nitrate is a major anthropogenic aerosol component exerts large radiative scattering (cooling) effect and is expected to dominate the aerosol cooling by the end of the century (Bellouin et al., 2011;Adams et al., 2001;Hauglustaine et al., 2014). However, in the IPCC estimation of climate change, nearly all CMIP5 (Coupled Model Intercomparison Project phase 5) global models (IPCC, 2013) and about half of ACCMIP (The Atmospheric Chemistry and Climate Model Intercomparison Project) global models (Shindell et al., 2013) did not take nitrate into consideration. Generally, models with a modal aerosol approach of M7 (an aerosol module, Vignati et al., 2004) or GLOMAP (Global Model of Aerosol Processes, Mann et al., 2010) do not consider nitrate, although some modified models might add nitrate in M7 and GLOMAP. For example, EMAC (ECHAM5/MESSy Atmospheric Chemistry model, Karydis et al., 2016) adopts an aerosol module similar as M7 and includes particulate nitrate (details below); the representation of nitrate is under developing for GLOMAP and waiting for activation in Hadley Centre Global Environmental Model (Bellouin et al., 2013).

The chemical and thermodynamic equilibrium of semi-volatile ammonium nitrate, i.e., its mass transfer between gas and particulate phases and partitioning in different sizes, appears to be crucial for modelling the size distribution and climate effect of particulate nitrate. Fully dynamic mass transfer approach, which considers the diversity of particulate chemical compositions and mass transfer flux across different particle sizes dynamically, is the best method to address this issue (Capaldo et al., 2000;Zaveri et al., 2008). However, it is computationally very expensive for the fully dynamic approach, due to the large difference in equilibrium time scale of different particle size bins, multicomponent and etc., see detailed description in the section 3 of Zaveri et al. (2008). The aerosol module MOSAIC (Model for Simulating Aerosol Interactions and Chemistry, Zaveri et al., 2008), was developed to address dynamic gas-particle partitioning in a relatively efficient way. It agreed well (Zaveri et al., 2008) with the benchmark equilibrium model AIM (Aerosol Inorganics Model, Wexler and Clegg, 2002) and was coupled into the regional chemical transport model WRF-Chem. Bulk equilibrium or 'hybrid method' (Capaldo et al., 2000) and other simplifications have been adopted for nitrate partitioning treatment in some global models for computational efficiency, but it is difficult for them to capture the 're-distribution effect' of nitrate, as described following.

In the GISS (Goddard Institute for Space Studies) model (Liao and Seinfeld, 2005), the gas-particle transfer of ammonium nitrate is represented by a bulk equilibrium approach over land. To calculate nitrate 
direct radiative forcing (DRF), the bulk nitrate mass is distributed into different size bins with a pre-fixed lognormal distribution. They are thus only able to take into account the impact of enhanced total nitrate mass concentration, but not the competition for nitric acid between fine and coarse modes nor the dynamic impact on aerosol number/mass size distributions. For example, with GISS GCM II global model, Liao and Seinfeld (2005) reported that heterogeneous reactions on the surface of natural source aerosols (including sea-salt and dust) increase the column burdens of particulate nitrate by $30-50 \%$ and thus lead to an strengthening of anthropogenic nitrate DRF by $0-2 \mathrm{~W} \mathrm{~m}^{-2}$ over Europe.

Xu and Penner (2012) investigated nitrate global DRF with the IMPACT (Integrated Massively Parallel Atmospheric Chemical Transport) global model, by treating the gas-particle transfer with a 'hybrid' method (Capaldo et al., 2000). It firstly employed a bulk equilibrium method for fine mode followed by a dynamic mass transfer method for coarse mode. This approach has limitation in considering the competitive consumption of gaseous precursors between fine and coarse mode particles, and is difficult to capture the continuous dynamic evolution of particles size and compositions distributions (Zaveri et al., 2008). Xu and Penner (2012) showed that sea-salt associated nitrate is one of the most important chemical pathway for the secondary formation of particulate nitrate, especially over Europe, ocean and coastal regions; however they mainly focused on the indirect radiative forcing of nitrate, the DRF of sea-salt associated-only nitrate was not well investigated.

Myhre et al. (2006) identifies the deficiency in Liao and Seinfeld (2005) and pointed out that sea-salt aerosol will deplete $\mathrm{HNO}_{3}$ and reduce AOD of fine mode nitrate. Myhre et al. (2006) used the Oslo CTM2, a global chemistry model off-line coupled with a meteorological module, to illustrate the impacts of sea-salt aerosol on fine mode nitrate and its AOD. The modelling study was based on state-of-the-art algorithms in 2006 and made some simplified assumptions to facilitate computational efficiency. For example, it was assumed that fine particles are entirely comprised by sulfate and coarse particles by sea-salt aerosol; the later on condensed fine mode ammonium nitrate was assumed to be externally mixed with a prefixed lognormal size distribution in optical calculation. This simplification improves computational efficiency but reduces the multicomponent level. The Equilibrium Simplified Aerosol Model (EQSAM, Metzger et al., 2002a; Metzger et al., 2002b) was implemented twice to solve the thermodynamic equilibrium firstly for fine mode and then followed by the coarse mode. However, to reduce the computational burden for a global model, the fully dynamic mass transfer between particle sizes was not considered in the study. With the bulk 
equilibrium method (EQSAM) and assuming an instant equilibrium for both fine and coarse mode particles, the 're-distribution effect' of nitrate could be overestimated since the coarse mode needs extended time to reach equilibrium (Myhre et al., 2006). Myhre et al. (2006) evaluated that the depletion of $\mathrm{HNO}_{3}$ by sea-salt aerosol may reduce $25 \%$ of $\mathrm{AOD}_{\text {nitrate }}$ in fine mode on a global scale, which is consistent with the upper limit of our estimation for Europe.

ISORROPIA (an aerosol thermodynamic model, Nenes et al., 1998) is adopted in the GEOS-Chem global CTM model, which consider particles as a bulk for the equilibrium. The partitioned nitrate is then proportioned to each size bin according to sulfate mass (Yu and Luo, 2009). In INCA (Interaction with Chemistry and Aerosols) model, the nitrate irreversibly condenses on particle surface (Bauer et al., 2004), therefore no equilibrium between gas and particulate phases. There is only accumulation mode nitrate in HadGEN2 model (the Earth system model of the UK Met Office Hadley Centre, Bellouin et al., 2011). Therefore, the 're-distribution' of pre-existing fine mode ammonium nitrate to sea-salt aerosol surface cannot be captured by these models.

EMAC adopts a modal aerosol approach similar to M7, with modification to include particulate nitrate (Karydis et al., 2016). It treats gas-particle partitioning with GMXe (Global Modal-aerosol eXtension, Pringle et al., 2010), and calculates the partitioning process in two stages. First, the amount of gaseous species which is able to kinetically condense on each mode is estimated, based on diffusion limited condensation. Second, ISORROPIA or EQSAM (choose either of them) is employed for thermodynamic calculation in each mode separately, assuming instant equilibrium between gas and particulate phase. The competition of existing nitric acid between fine and coarse modes can be partly considered in this treatment. However, ISORROPIA and EQSAM are both bulk approaches, and the diversity of components in different particle sizes is not considered. In the EMAC model, the association of nitrate with fine and coarse mode particles is considered separately. When abundant sea-salt aerosol mixes with a nitrate-rich air mass, the ambient gaseous precursors may not suffice for condensation. The evaporation of fine mode ammonia nitrate can complement the shortage of gaseous species, and a significant 're-distribution effect' occurs. A fully dynamic mass transfer approach would provide more insight in the 're-distribution effect'. 


\section{Section S2. WRF-Chem simulation}

The WRF-Chem model was driven by NCEP reanalysis data $\left(1^{\circ} \times 1^{\circ}\right.$ resolution and provided every 6 hours), including the Final Analysis Operational Global Analysis (http://rda.ucar.edu/datasets/ds083.2/) and

91 the sea surface temperature datasets (http://polar.ncep.noaa.gov/sst/). The first two days were spin-up runs

92 for simulations in this study. The nudging is carried out in every 6 hours for meteorological conditions, including wind, temperature and moisture.

94 The inventory, provided by TNO for the EUCAARI project (Kulmala et al., 2011), was adopted for the elemental carbon anthropogenic emission, with exclusion of point sources over Germany due to their remarkable uncertainties (Chen et al., 2016b). The hourly Fire INventory from NCAR (FINN, Wiedinmyer et al., 2011), with a horizontal resolution of $1 \mathrm{~km}$, was employed. Model of Emissions of Gases and Aerosols from Nature (MEGAN, Guenther et al., 2006) was on-line coupled to provide biogenic emissions.

In this study, dust emission was not considered, because of its negligible contribution to total particle mass concentration during HOPE-Melpitz (Chen et al., 2016a) campaign, and besides, large uncertainty was reported for the parameterization of the dust emission in WRF-Chem (Saide et al., 2012).

102

The 'Gong' sea-salt aerosol emission scheme (Gong, 2003) was adopted with total sea-salt aerosol

103 emission been reduced to 10\% in the 'Case_SeasaltOn' (Chen et al., 2016a). The modelled sea-salt mass

104 concentrations were in good agreements with measurements over coastal region from European Monitoring and Evaluation Programme (EMEP, http://www.emep.int), with a factor (and correlation coefficient) of 0.85 (0.67), $1.16(0.80)$ and 0.83 (0.87) respectively for Bilthoven, Kollumerwaard and Vredepeel (Fig. S3). 
The modelled aerosol optical depth (AOD) was evaluated against the AERONET dataset 111 (AErosol RObotic NETwork, http://aeronet.gsfc.nasa.gov/, Level 2.0) over Europe. The direct (collimated)

112 solar radiation observed by sun photometer was used to derive the AOD, which were pre- and post-field 113 calibrated, manually inspected and automatically cloud cleared. The AOD at $550 \mathrm{~nm}$ wavelength was derived 114 from the $500 \mathrm{~nm}$ wavelength data and the Ångström index in AERONET dataset. Please find more details 115 about AERONET in http://aeronet.gsfc.nasa.gov/.

116 The simulated AOD (550 nm wavelength) of the 'Case_SeasaltOn' was validated with the AERONET 117 AOD measurements over Europe during 10-20 September 2013. The comparison was made in the daytime 118 under clear-sky condition, when AERONET measurements were available, the highest AOD was found in 119 the inland European region by both simulated and measured AOD, followed by the coastal regions, whereas the lowest AOD was found over Alpine regions. Generally, the pattern of AOD spatial distribution can be captured by model $(\mathrm{R}=0.64)$, although it was overall overestimated with a geometric mean ratio (GMR) value of 1.7. Despite of some shortcomings of AOD modelling, the general performance is satisfactory and in line with previous studies (Li et al., 2013;Xu and Penner, 2012). The overestimation of AOD was reduced in our 'Case_SeasaltOn' (sea-salt emission in a factor of 1) compared with Chen et al. (2016a), which reported an overestimation of AOD with GMR of 2.3 (F-CASE, sea-salt emission in a factor of 10) and 1.8 (R-CASE, sea-salt emission in a factor of 0.5). The reduction of sea-salt aerosol contributes to the shrink of AOD when compare with the reported F-CASE, however, reduction of sea-salt aerosol should not be the reason of decreasing GMR when compare with the R-CASE. The 're-distribution effect' of nitrate particle mass size distribution could be the reason for this.

\section{Section S4. Competition between 're-distribution effect' and 'mass-enhancement effect'}

The direct radiative forcing (DRF) of aerosol is strongly related with its aerosol optical depth (AOD) (Wang et al., 2014). During daytime on 19 September when marine air masses brought sea-salt aerosol to northern Poland, the nitrate AOD significantly decreased as a function of sea-salt mass concentration $\left(\left[\mathrm{Na}^{+}\right]\right)$, 
and 6a). As shown in Fig. 7a, the 're-distribution effect' can averagely reduce AOD of nitrate ( $\left.\mathrm{AOD}_{\text {nitrate }}\right)$ by

$139 \sim 20 \%$ when abundant sea-salt present with a molar ratio between particulate nitrate and sodium (RNS)

140 smaller than 1 , and reduce by $10-20 \%$ over regions where relatively high nitrate loading present with $1<$

141 RNS $<30$. On the other hand, the sea-salt-induced increase of particulate nitrate mass concentration $\left(\left[\mathrm{NO}_{3}{ }^{-}\right.\right.$

142 ], 'mass-enhancement effect') may enhance AOD $_{\text {nitrate }}$ (Liao and Seinfeld, 2005). The AOD nitrate could 143 increase by up to $30 \%$ averagely by introducing sea-salt if only 'mass-enhancement effect' is considered

144 (Fig. 7b). Fig. 7c shows the net effect as competition between the sea-salt-induced 're-distribution' and 145 'mass-enhancement' effects. The clear-sky results over the entire European domain were used for the 146 statistical analysis when sea-salt aerosol was transported over the European continent during 16-20

147 September. In sea-salt-rich air masses (RNS < 1), which mostly appear over the oceanic regions, the net 148 effect tends to increase $\mathrm{AOD}_{\text {nitrate }}$ (as shown in Fig. 5a and Fig. 6b). Conversely, the 're-distribution effect' 149 tends to overwhelm the 'mass-enhancement effect' resulting in a net effect with decreasing $\mathrm{AOD}_{\text {nitrate }}$ when

150 the RNS is higher than 1. This is because a considerable amount of particulate nitrate is shifted from the fine 151 to the coarse mode ('re-distribution effect') by the heterogeneous reactions on the surface of sea-salt aerosol and change of gas-particle equilibrium (Fig. 1). The largest mean value of $\mathrm{AOD}_{\text {nitrate }}$ net reduction over

153 Europe was $\sim 6 \%$ when RNS is $\sim 10$, with $\sim 25 \%$ probability of $\mathrm{AOD}_{\text {nitrate }}$ net reduction by more than $10 \%$

154 (Fig. 7c). The mean value of reduction starts to decrease as RNS increases when RNS > 10. A possible explanation is that air masses with high $\left[\mathrm{NO}_{3}^{-}\right]$are accompanied by a high level of anthropogenic NOx, and hence more sodium chloride is consumed by the sea-salt-induced 'mass-enhancement effect', outcompeting

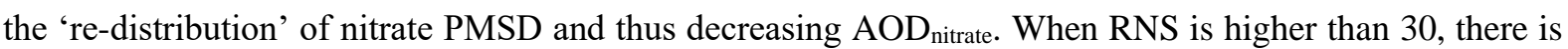
no significant change in $\mathrm{AOD}_{\text {nitrate }}(\sim 50 \%$ probability for both increasing and decreasing), because of the very limited loading of sea-salt aerosol. In general, (1) the sea-salt-induced 'mass-enhancement effect' is

160 dominant over oceanic regions and tends to increase $\mathrm{AOD}_{\text {nitrate }}$ when RNS is lower than 1; (2) the sea-saltinduced 're-distribution effect' on nitrate PMSD can decrease AOD $_{\text {nitrate }}$ by about 10-20\% and overwhelm the 'mass-enhancement effect' resulting in a net reduction of $\mathrm{AOD}_{\text {nitrate }}$ when $1<\mathrm{RNS}<30$; and (3) the influence of sea-salt aerosol is not significant when RNS is higher than 30 . 
167 Section S5. Moderating total aerosol cooling by the 're-distribution effect' on nitrate

168 The reduction of nitrate AOD may even lead to a decrease of total aerosol radiative effect; however, it 169 is non-monotonic with sea-salt aerosol loading due to competition between the increasing of sea-salt AOD 170 and decreasing of nitrate AOD. As shown in Fig. S6b, the total aerosol AOD (AOD ${ }_{\text {total }}$, black line indicates 171 the change of $\mathrm{AOD}_{\text {total }}$ ) firstly decreases with increasing $\left[\mathrm{Na}^{+}\right]$and reaches the largest reduction of 0.03 $172(\sim 11 \%)$ when $\left[\mathrm{Na}^{+}\right]$was about $0.4-0.6 \mu \mathrm{g} \mathrm{m}^{-3}$ in the 'Case_SeasaltOn'. Later, with further enhanced sea-salt 173 aerosol emissions, the increase of sea-salt $\mathrm{AOD}\left(\mathrm{AOD}_{\mathrm{NaCl}}\right)$ compensates the decrease of $\mathrm{AOD}_{\text {nitrate }}$ and 174 dominates the change of $\mathrm{AOD}_{\text {total }}$, eventually leading to a slow increase of $\mathrm{AOD}_{\text {total }}$ up to $\sim 10 \%$ with a sea175 salt aerosol emission factor of 10 . Our results indicate that the natural sea-salt aerosol may reduce the total 176 light extinction when marine air masses mix with nitrate-rich air masses and sea-salt concentration is still 177 relatively low. In view of Europe, this critical $\left[\mathrm{Na}^{+}\right]$is estimated to be $\sim 4-7 \mu \mathrm{g} \mathrm{m}^{-3}$, see Fig. S6b and similar 178 results at Melpitz/Leipzig (not shown here). For more polluted regions, such as the North China Plain and 179 India, the critical $\left[\mathrm{Na}^{+}\right]$is expected to be higher. The measurements of $\left[\mathrm{Na}^{+}\right]$in Germany (Neumann et al., 180 2016), Florida USA (Gantt et al., 2015), and Sweden (Gustafsson and Franzén, 2000), where considerable 181 amounts of sea-salt associated nitrate (about 1-3 ppbv, about 35-90\% of total nitrate) are found (Xu and 182 Penner, 2012), are summarized in Fig. 6c. Broadly speaking, the $\left[\mathrm{Na}^{+}\right]$in these regions are in the range of $1830-5 \mu \mathrm{g} \mathrm{m}^{-3}$, with very rare exceptions at Westerland Germany (a coastal station) in winter. A similar level of 184 sea-salt associated nitrate is reported by a regional model study over coastal regions of China and western 185 Pacific Ocean ( $\mathrm{Li}$ et al. 2018). This implies that the reduction of total aerosols light extinction due to sea186 salt-induced 're-distribution effect' may be commonly observed over the European continent, the coastal 187 and outflow regions of US and China.

188

189

190

191

192 
Our 'Case_SeasaltOff' and 'Case_SeasaltOn' simulations overestimate particulate nitrate mass concentration by a factor of $\sim 5$ compared with filter measurements at Melpitz. Overestimation of particulate

196 nitrate is a common issue of simulations over Europe. Lecœur and Seigneur (2013) performed a 9-year 197 simulation over Europe using Polyphemus/Polair3D model, validated model results with observations from 198 EMEP stations and compared their results with AQMEII models (including CHIMERE, CALIOPE-EU, 199 WRF-Chem and CMAQ). They found that all models overestimate particulate nitrate over Europe. 200 Polyphemus/Polair3D model overestimates by a factor of 1-3 during summer (Lecœur and Seigneur, 2013); WRF-Chem overestimates by a factor of 3-6 during September (Tuccella et al., 2012); CHIMERE performs the best among all models but still overestimates nitrate by a factor of 1.7 during September-November (Péré et al., 2010). Another recent study carried out European simulation over period of 1994-2014 using a regional climate model (ALADIN-Climate) and validated nitrate simulation with surface observations from 33 EMEP stations (Drugé et al., 2019). They found that, i) nitrate starts to play the most important role on aerosol radiative forcing over Europe since 2005; ii) their model is able to reproduce surface distribution of nitrate however generally overestimate nitrate by factors of 2-5. The above results indicate that nitrate simulation in our model is within a comparable range with previous studies.

The 're-distribution effect' on nitrate is captured well in our simulations (Fig. 4), although particulate nitrate mass is overestimated. This overestimation can lead to a more conservative assessment of $\triangle \mathrm{AOD}_{\text {nitrate }}$

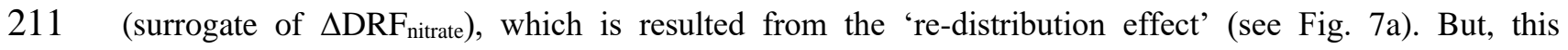

212 overestimation of nitrate would not have significant influence on the assessment of percentage change in

$213 \mathrm{AOD}_{\text {nitrate. }}$ Remarkable 're-distribution effect' occurs in the regime of $1<\mathrm{RNS}<30$, where consists of $\sim 70 \%$

214 European results and $\mathrm{AOD}_{\text {nitrate }}$ is reduced by about $10-20 \%$ (Fig. 7a). The percentage change of $\mathrm{AOD}_{\text {nitrate }}$ 215 decreases very slowly as increase of RNS, which is proportional to nitrate mass concentration. A smaller $216\left[\mathrm{NO}_{3}{ }^{-}\right]$(or RNS) by a factor of 5 generally leads to a greater decreasing of $\mathrm{AOD}_{\text {nitrate }}$ in percentage by less

217 than $10 \%$ (Fig. 7a). Therefore, our assessment of moderation in $\mathrm{AOD}_{\text {nitrate }}$ resulted from 're-distribution 218 effect' is robust (slightly conservative) and not significantly influenced by nitrate overestimation in this 219 study. 
a

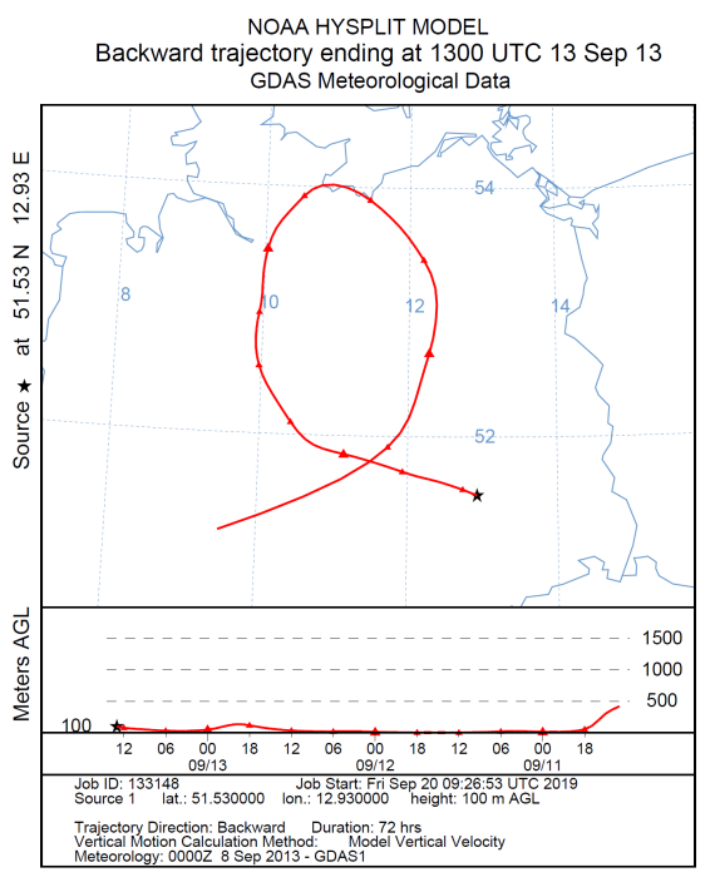

b

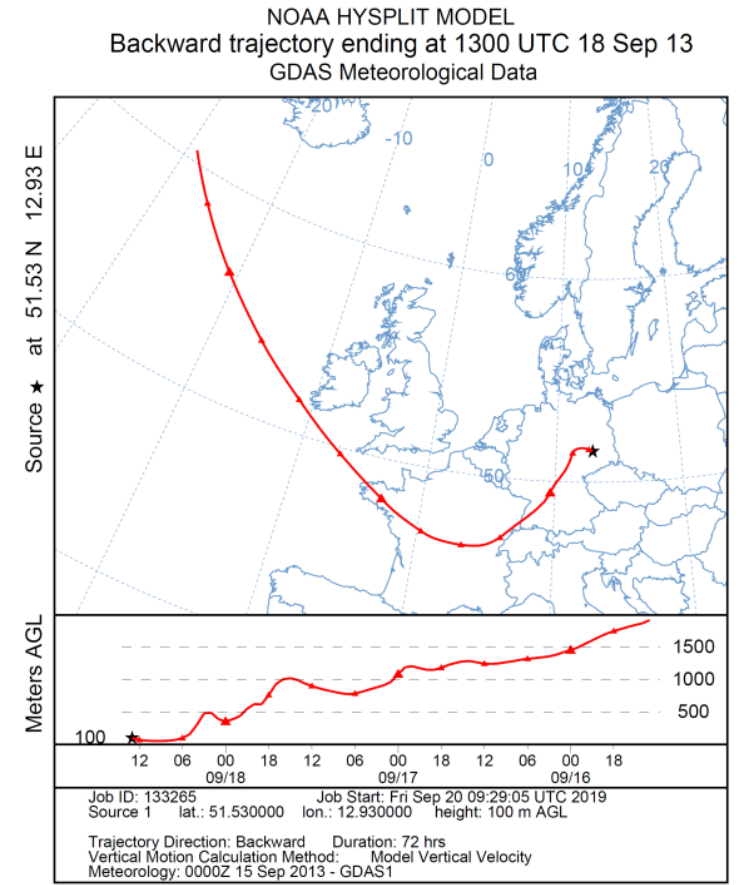

Fig. S1. Three days back-trajectories for Melpitz, Germany. (a) 13 September 2013, representing continental period; (b) 18 September 2013, representing marine period. The back-trajectories are calculated by Hysplit (https://www.ready.noaa.gov/HYSPLIT.php).

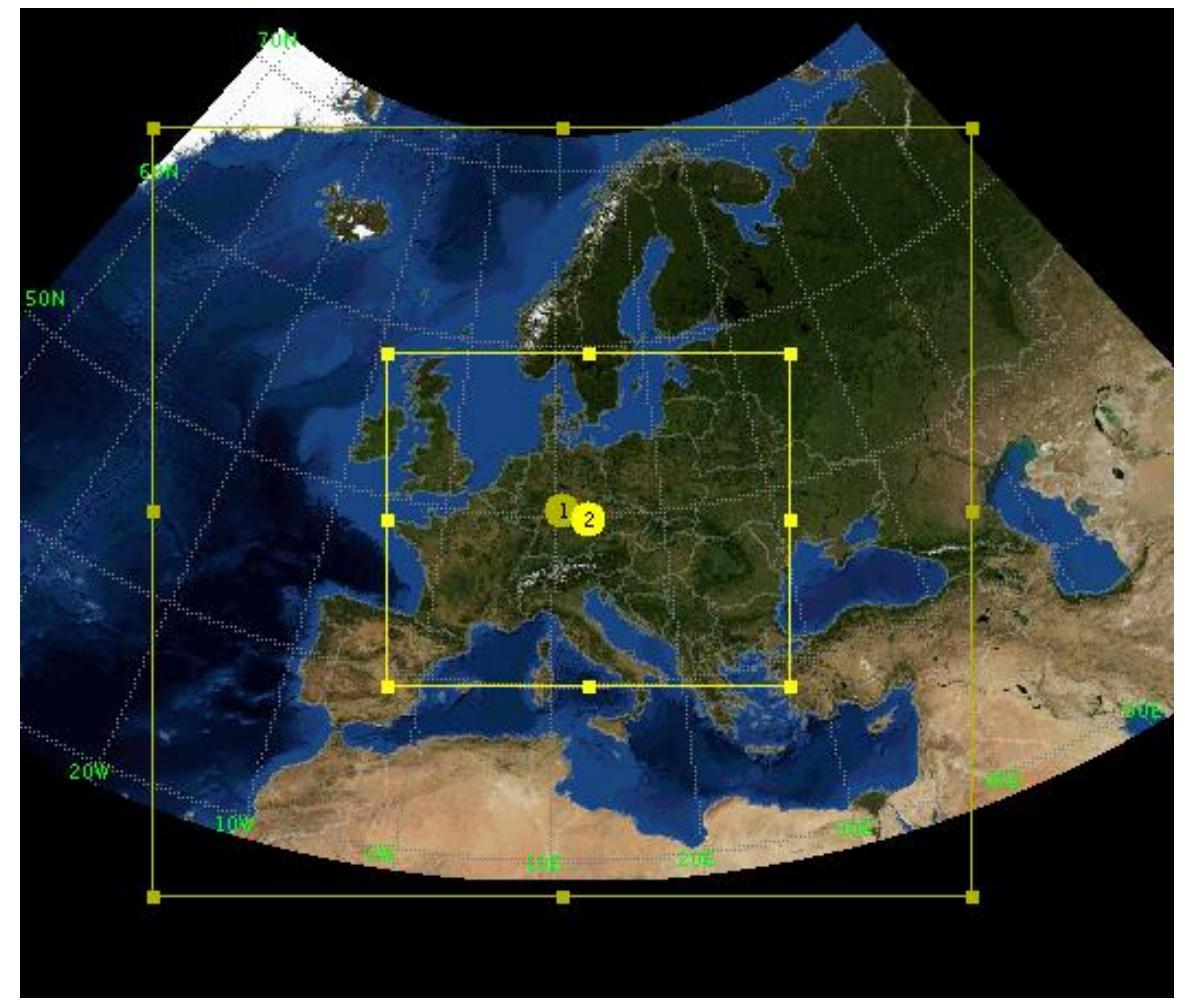

Fig. S2. Domain setting of WRF-Chem European case. 
a

Bilthoven

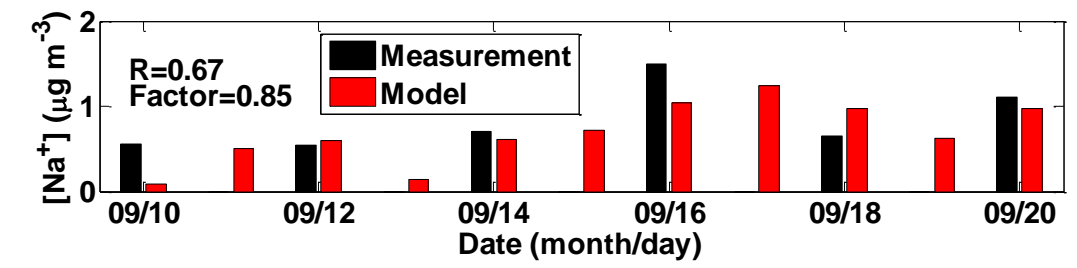

b

Kollumerwaard

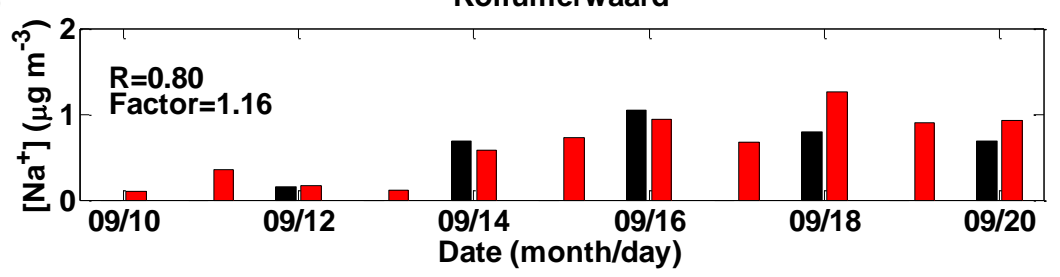

C

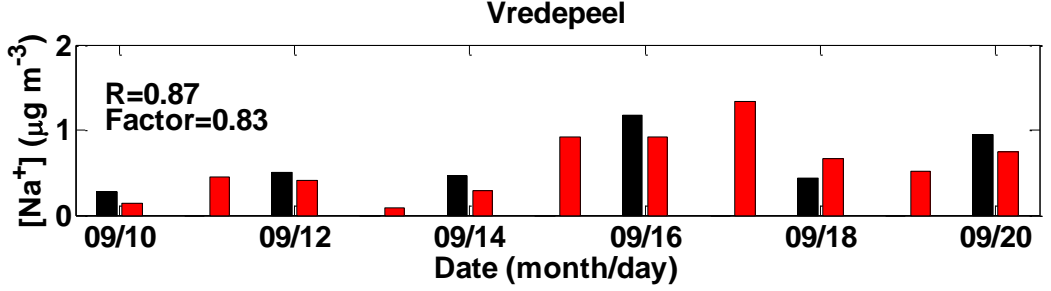

Fig. S3. Comparisons of sodium mass concentration $\left(\left[\mathbf{N a}^{+}\right]\right)$in $\mathbf{P M} \mathbf{M}_{\mathbf{1 0}}$. The filter sampler measurements at EMEP stations (Chen et al., 2016a) are in black bars, and the 'Case_SeasaltOn' model results are in red bars. a, Bilthoven. b, Kollumerwaard. c, Vredepeel. The locations of stations are shown in Fig. 3.

a

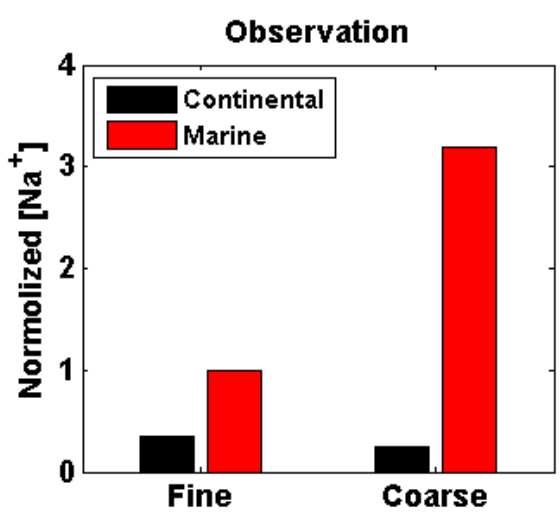

b

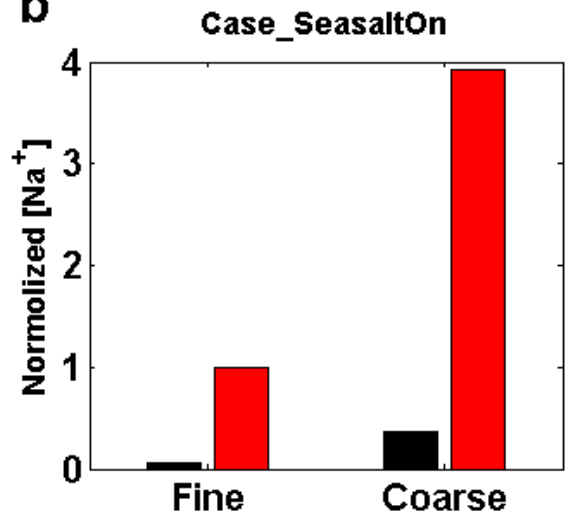

Fig. S4. Sodium mass concentration $\left(\left[\mathrm{Na}^{+}\right]\right)$normalized with the fine mode sodium concentration during the marine period. a, Berner impactor measurements. b, WRF-Chem 'Case_SeasaltOn', i.e., with sea-salt emission. The results are grouped into continental (black bar) and marine (red bar) air mass types, respectively. The fine and coarse mode particles are defined as $\mathrm{PM}_{1.2}$ (particles with aerodynamic diameter smaller than $1.2 \mu \mathrm{m}$ ) and $\mathrm{PM}_{1.2-10}$ (particles with aerodynamic diameter between $1.2 \mu \mathrm{m}$ and $10 \mu \mathrm{m}$ ), respectively. Note: the sodium is negligible $\left(<0.5 \mu \mathrm{g} \mathrm{m}^{-3}\right)$ for the 'Case_SeasaltOff' simulated without sea-salt emission. 


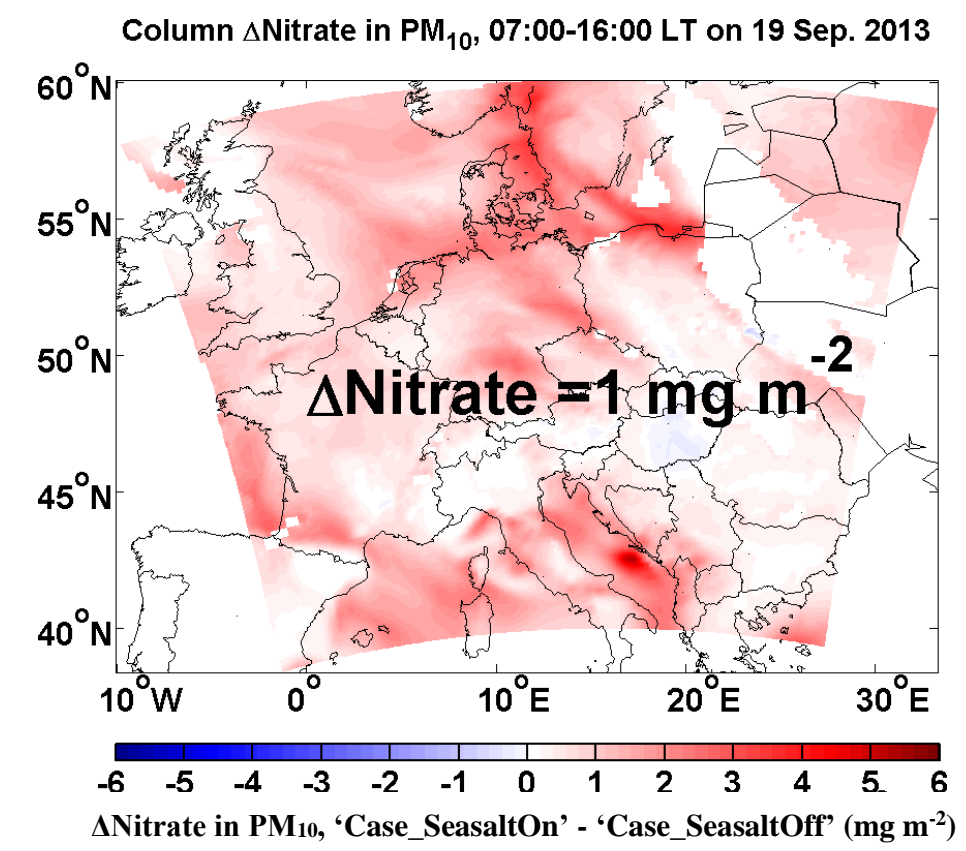

Fig. S5. Influence of sea-salt aerosol on the simulated column nitrate loading in $\mathbf{P M}_{10}$ ( $\Delta$ Nitrate). The simulated $\Delta$ Nitrate between the 'Case_SeasaltOn' and 'Case_SeasaltOff' simulations showed here are averaged during daytime, i.e., 07:00-16:00 local time (LT) on 19 September 2013. 
a

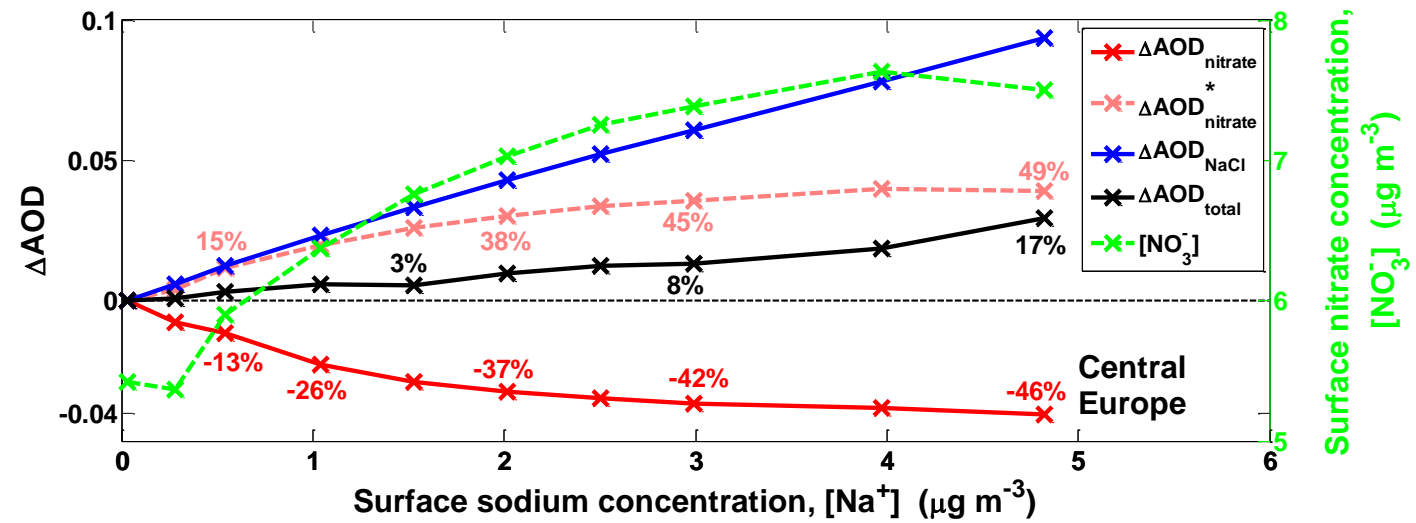

b

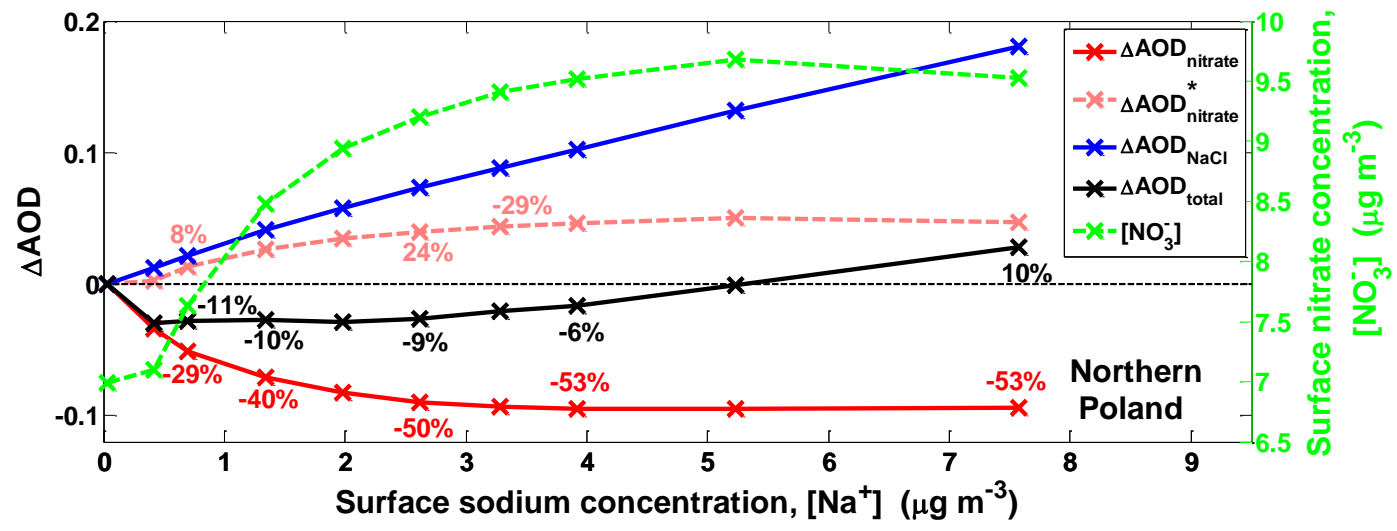

Fig. S6. Similar as Fig. 6. The additional black lines indicate the changes of total AOD $\left(\triangle A O D_{\text {total }}\right)$, including the reduction of nitrate $\mathrm{AOD}\left(\triangle \mathrm{AOD} \mathrm{D}_{\text {nitrate }}\right)$ and the enhancement of sea-salt $\mathrm{AOD}\left(\triangle \mathrm{AOD}_{\mathrm{NaCl}}\right)$. a, Central Europe region; b, Northern Poland region. The regions are marked in Fig. 3. 


\section{Column $\triangle$ Nitrate, 16:00-22:00 UTC on 10-17 Jan. 2015}

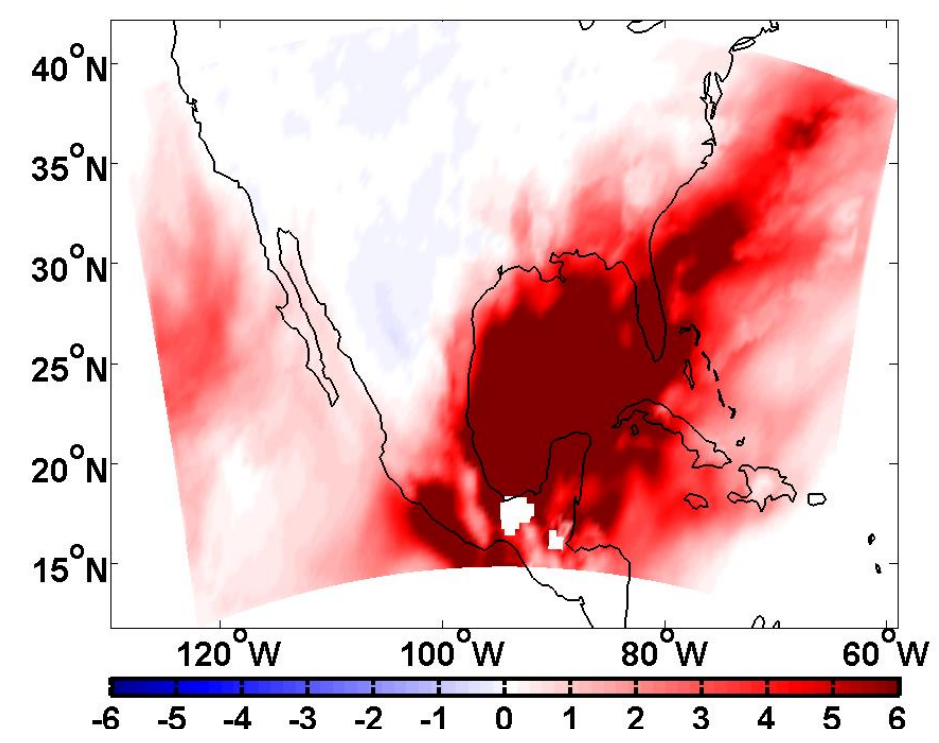

$\Delta$ Nitrate in PM10, 'Case_SeasaltOn' - 'Case_SeasaltOff' $\left(\mathrm{mg} \mathrm{m}^{-2}\right)$

Fig. S7. Influence of sea-salt aerosol on the simulated column nitrate loading in $\mathbf{P M}_{10}$ ( $\Delta$ Nitrate). The simulated $\Delta$ Nitrate between the 'Case_SeasaltOn' and 'Case_SeasaltOff' simulations showed here are averaged during the daytime over North America, i.e., 16:00-22:00 (UTC) on 10-17 January 2015. 


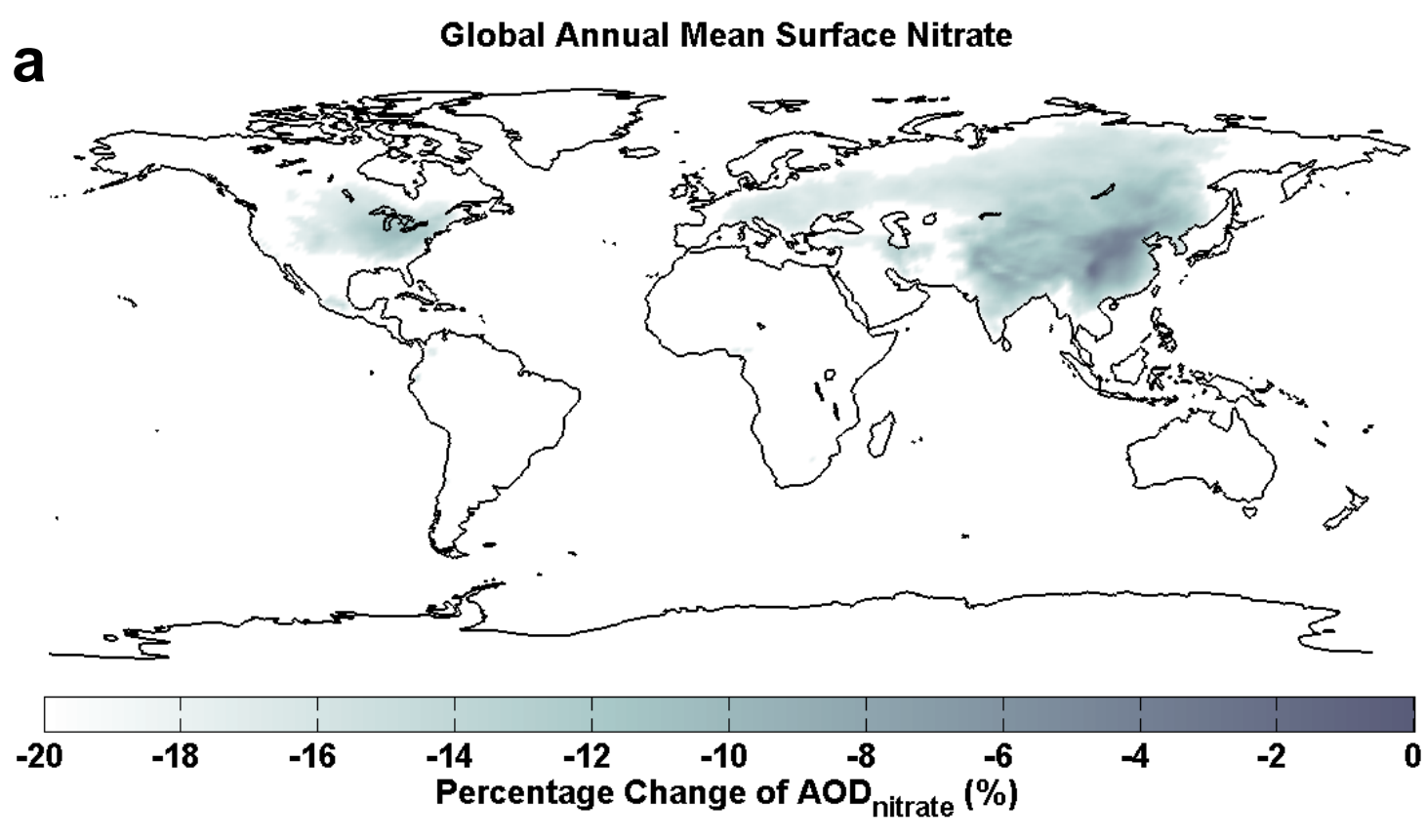

b Global Annual Mean Surface Nitrate

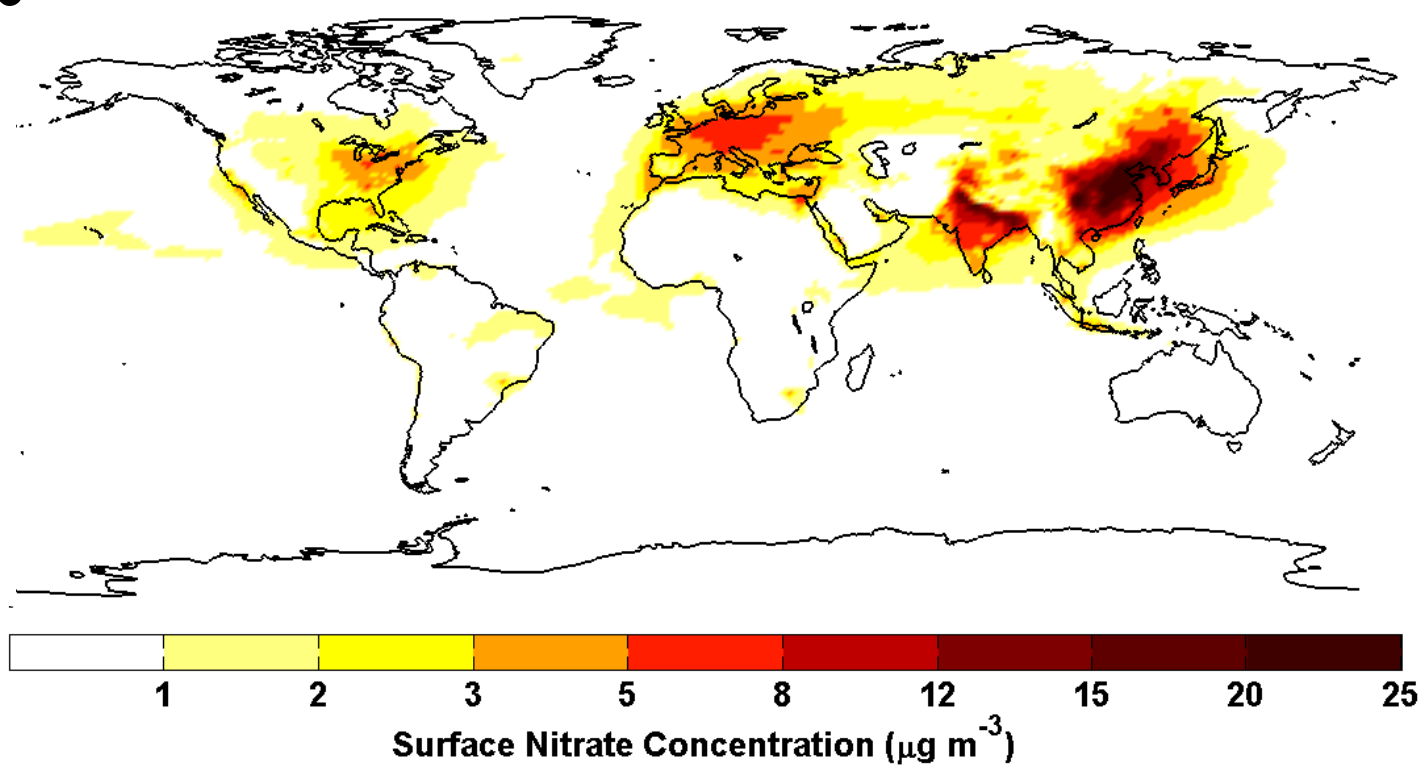

Fig. S8. Global distribution of percentage changes of $\mathrm{AOD}_{\text {nitrate }}(\mathrm{a})$ and surface nitrate concentration (b). The results are from EMAC model. 


\section{References for SI:}

Adams, P. J., Seinfeld, J. H., Koch, D., Mickley, L., and Jacob, D.: General circulation model assessment of direct radiative forcing by the sulfate-nitrate-ammonium-water inorganic aerosol system, Journal of Geophysical Research: Atmospheres, 106, 1097-1111, 10.1029/2000JD900512, 2001.

Bauer, S. E., Balkanski, Y., Schulz, M., Hauglustaine, D. A., and Dentener, F.: Global modeling of heterogeneous chemistry on mineral aerosol surfaces: Influence on tropospheric ozone chemistry and comparison to observations, Journal of Geophysical Research: Atmospheres, 109, D02304, 10.1029/2003JD003868, 2004.

Bellouin, N., Rae, J., Jones, A., Johnson, C., Haywood, J., and Boucher, O.: Aerosol forcing in the Climate Model Intercomparison Project (CMIP5) simulations by HadGEM2-ES and the role of ammonium nitrate, Journal of Geophysical Research: Atmospheres, 116, D20206, 10.1029/2011JD016074, 2011.

Bellouin, N., Mann, G. W., Woodhouse, M. T., Johnson, C., Carslaw, K. S., and Dalvi, M.: Impact of the modal aerosol scheme GLOMAP-mode on aerosol forcing in the Hadley Centre Global Environmental Model, Atmos. Chem. Phys., 13, 3027-3044, 10.5194/acp-13-3027-2013, 2013.

Capaldo, P. K., Pilinis, C., and Pandis, S. N.: A computationally efficient hybrid approach for dynamic gas/aerosol transfer in air quality models, Atmospheric Environment, 34, 3617-3627, http://dx.doi.org/10.1016/S1352-2310(00)00092-3, 2000.

Chen, Y., Cheng, Y., Ma, N., Wolke, R., Nordmann, S., Schüttauf, S., Ran, L., Wehner, B., Birmili, W., van der Gon, H. A. C. D., Mu, Q., Barthel, S., Spindler, G., Stieger, B., Müller, K., Zheng, G. J., Pöschl, U., Su, H., and Wiedensohler, A.: Sea salt emission, transport and influence on size-segregated nitrate simulation: a case study in northwestern Europe by WRF-Chem, Atmos. Chem. Phys., 16, 12081-12097, 10.5194/acp-16-12081-2016, 2016a.

Chen, Y., Cheng, Y. F., Nordmann, S., Birmili, W., Denier van der Gon, H. A. C., Ma, N., Wolke, R., Wehner, B., Sun, J., Spindler, G., Mu, Q., Pöschl, U., Su, H., and Wiedensohler, A.: Evaluation of the size segregation of elemental carbon (EC) emission in Europe: influence on the simulation of EC longrange transportation, Atmos. Chem. Phys., 16, 1823-1835, 10.5194/acp-16-1823-2016, $2016 \mathrm{~b}$.

Drugé, T., Nabat, P., Mallet, M., and Somot, S.: Model simulation of ammonium and nitrate aerosols distribution in the Euro-Mediterranean region and their radiative and climatic effects over 19792016, Atmos. Chem. Phys., 19, 3707-3731, 10.5194/acp-19-3707-2019, 2019.

Gantt, B., Kelly, J. T., and Bash, J. O.: Updating sea spray aerosol emissions in the Community Multiscale Air Quality (CMAQ) model version 5.0.2, Geosci. Model Dev., 8, 3733-3746, 10.5194/gmd-83733-2015, 2015.

Gong, S. L.: A parameterization of sea-salt aerosol source function for sub- and super-micron particles, Global Biogeochemical Cycles, 17, 10.1029/2003GB002079, 2003.

Guenther, A., Karl, T., Harley, P., Wiedinmyer, C., Palmer, P. I., and Geron, C.: Estimates of global terrestrial isoprene emissions using MEGAN (Model of Emissions of Gases and Aerosols from Nature), Atmos. Chem. Phys., 6, 3181-3210, 10.5194/acp-6-3181-2006, 2006.

Gustafsson, M. E. R., and Franzén, L. G.: Inland transport of marine aerosols in southern Sweden, Atmospheric Environment, 34, 313-325, http://dx.doi.org/10.1016/S1352-2310(99)00198-3, 2000.

Hauglustaine, D. A., Balkanski, Y., and Schulz, M.: A global model simulation of present and future nitrate aerosols and their direct radiative forcing of climate, Atmos. Chem. Phys., 14, 11031-11063, 10.5194/acp-14-11031-2014, 2014.

IPCC: Climate Change 2013: The Physical Science Basis. Contribution of Working Group I to the Fifth Assessment Report of the Intergovernmental Panel on Climate Change, Report, edited by: Stocker, T. F., Qin D. H., Plattner, G. K., Tignor, M. M. B., Allen, S. K., Boschung, J., Nauels, A., Xia, Y., Bex, V., and Midgley, P. M., Cambridge University Press, New York, available at: http://www.ipcc.ch/report/ar5 (last access: 10 September, 2016), 2013.

Karydis, V. A., Tsimpidi, A. P., Pozzer, A., Astitha, M., and Lelieveld, J.: Effects of mineral dust on global atmospheric nitrate concentrations, Atmos. Chem. Phys., 16, 1491-1509, 10.5194/acp-16-14912016, 2016.

Kulmala, M., Asmi, A., Lappalainen, H. K., Baltensperger, U., Brenguier, J. L., Facchini, M. C., Hansson, 
H. C., Hov, Ø., O'Dowd, C. D., Pöschl, U., Wiedensohler, A., Boers, R., Boucher, O., de Leeuw, G., Denier van der Gon, H. A. C., Feichter, J., Krejci, R., Laj, P., Lihavainen, H., Lohmann, U., McFiggans, G., Mentel, T., Pilinis, C., Riipinen, I., Schulz, M., Stohl, A., Swietlicki, E., Vignati, E., Alves, C., Amann, M., Ammann, M., Arabas, S., Artaxo, P., Baars, H., Beddows, D. C. S., Bergström, R., Beukes, J. P., Bilde, M., Burkhart, J. F., Canonaco, F., Clegg, S. L., Coe, H., Crumeyrolle, S., D'Anna, B., Decesari, S., Gilardoni, S., Fischer, M., Fjaeraa, A. M., Fountoukis, C., George, C., Gomes, L., Halloran, P., Hamburger, T., Harrison, R. M., Herrmann, H., Hoffmann, T., Hoose, C., Hu, M., Hyvärinen, A., Hõrrak, U., Iinuma, Y., Iversen, T., Josipovic, M., Kanakidou, M., KiendlerScharr, A., Kirkevåg, A., Kiss, G., Klimont, Z., Kolmonen, P., Komppula, M., Kristjánsson, J. E., Laakso, L., Laaksonen, A., Labonnote, L., Lanz, V. A., Lehtinen, K. E. J., Rizzo, L. V., Makkonen, R., Manninen, H. E., McMeeking, G., Merikanto, J., Minikin, A., Mirme, S., Morgan, W. T., Nemitz, E., O'Donnell, D., Panwar, T. S., Pawlowska, H., Petzold, A., Pienaar, J. J., Pio, C., Plass-Duelmer, C., Prévôt, A. S. H., Pryor, S., Reddington, C. L., Roberts, G., Rosenfeld, D., Schwarz, J., Seland, Ø., Sellegri, K., Shen, X. J., Shiraiwa, M., Siebert, H., Sierau, B., Simpson, D., Sun, J. Y., Topping, D., Tunved, P., Vaattovaara, P., Vakkari, V., Veefkind, J. P., Visschedijk, A., Vuollekoski, H., Vuolo, R., Wehner, B., Wildt, J., Woodward, S., Worsnop, D. R., van Zadelhoff, G. J., Zardini, A. A., Zhang, K., van Zyl, P. G., Kerminen, V. M., S Carslaw, K., and Pandis, S. N.: General overview: European Integrated project on Aerosol Cloud Climate and Air Quality interactions (EUCAARI) \&ndash; integrating aerosol research from nano to global scales, Atmos. Chem. Phys., 11, 13061-13143, 10.5194/acp-11-13061-2011, 2011.

Lecœur, Ė., and Seigneur, C.: Dynamic evaluation of a multi-year model simulation of particulate matter concentrations over Europe, Atmos. Chem. Phys., 13, 4319-4337, 10.5194/acp-13-4319-2013, 2013.

Li, J., Han, Z., and Yao, X.: A modeling study of the influence of sea salt on inorganic aerosol concentration, size distribution, and deposition in the western Pacific Ocean, Atmospheric Environment, https://doi.org/10.1016/j.atmosenv.2018.06.030, 2018.

Li, S., Garay, M. J., Chen, L., Rees, E., and Liu, Y.: Comparison of GEOS-Chem aerosol optical depth with AERONET and MISR data over the contiguous United States, Journal of Geophysical Research: Atmospheres, 118, 11,228-211,241, 10.1002/jgrd.50867, 2013.

Liao, H., and Seinfeld, J. H.: Global impacts of gas-phase chemistry-aerosol interactions on direct radiative forcing by anthropogenic aerosols and ozone, Journal of Geophysical Research: Atmospheres, 110, D18208, 10.1029/2005JD005907, 2005.

Mann, G. W., Carslaw, K. S., Spracklen, D. V., Ridley, D. A., Manktelow, P. T., Chipperfield, M. P., Pickering, S. J., and Johnson, C. E.: Description and evaluation of GLOMAP-mode: a modal global aerosol microphysics model for the UKCA composition-climate model, Geosci. Model Dev., 3, 519-551, 10.5194/gmd-3-519-2010, 2010.

Metzger, S., Dentener, F., Krol, M., Jeuken, A., and Lelieveld, J.: Gas/aerosol partitioning 2. Global modeling results, Journal of Geophysical Research: Atmospheres, 107, ACH 17-11-ACH 17-23, 10.1029/2001JD001103, 2002a.

Metzger, S., Dentener, F., Pandis, S., and Lelieveld, J.: Gas/aerosol partitioning: 1. A computationally efficient model, Journal of Geophysical Research: Atmospheres, 107, 4312, 10.1029/2001JD001102, 2002b.

Myhre, G., Grini, A., and Metzger, S.: Modelling of nitrate and ammonium-containing aerosols in presence of sea salt, Atmos. Chem. Phys., 6, 4809-4821, 10.5194/acp-6-4809-2006, 2006.

Nenes, A., Pandis, S. N., and Pilinis, C.: ISORROPIA: A New Thermodynamic Equilibrium Model for Multiphase Multicomponent Inorganic Aerosols, Aquatic Geochemistry, 4, 123-152, 10.1023/a:1009604003981, 1998.

Neumann, D., Matthias, V., Bieser, J., Aulinger, A., and Quante, M.: A comparison of sea salt emission parameterizations in northwestern Europe using a chemistry transport model setup, Atmos. Chem. Phys., 16, 9905-9933, 10.5194/acp-16-9905-2016, 2016.

Péré, J. C., Mallet, M., Pont, V., and Bessagnet, B.: Evaluation of an aerosol optical scheme in the chemistrytransport model CHIMERE, Atmospheric Environment, 44, 3688-3699, https://doi.org/10.1016/j.atmosenv.2010.06.034, 2010.

Pringle, K. J., Tost, H., Message, S., Steil, B., Giannadaki, D., Nenes, A., Fountoukis, C., Stier, P., Vignati, E., and Lelieveld, J.: Description and evaluation of GMXe: a new aerosol submodel for global 
simulations (v1), Geosci. Model Dev., 3, 391-412, 10.5194/gmd-3-391-2010, 2010.

Saide, P. E., Spak, S. N., Carmichael, G. R., Mena-Carrasco, M. A., Yang, Q., Howell, S., Leon, D. C., Snider, J. R., Bandy, A. R., Collett, J. L., Benedict, K. B., de Szoeke, S. P., Hawkins, L. N., Allen, G., Crawford, I., Crosier, J., and Springston, S. R.: Evaluating WRF-Chem aerosol indirect effects in Southeast Pacific marine stratocumulus during VOCALS-REx, Atmos. Chem. Phys., 12, 3045-3064, 10.5194/acp-12-3045-2012, 2012.

Shindell, D. T., Lamarque, J. F., Schulz, M., Flanner, M., Jiao, C., Chin, M., Young, P. J., Lee, Y. H., Rotstayn, L., Mahowald, N., Milly, G., Faluvegi, G., Balkanski, Y., Collins, W. J., Conley, A. J., Dalsoren, S., Easter, R., Ghan, S., Horowitz, L., Liu, X., Myhre, G., Nagashima, T., Naik, V., Rumbold, S. T., Skeie, R., Sudo, K., Szopa, S., Takemura, T., Voulgarakis, A., Yoon, J. H., and Lo, F.: Radiative forcing in the ACCMIP historical and future climate simulations, Atmos. Chem. Phys., 13, 29392974, 10.5194/acp-13-2939-2013, 2013.

Tuccella, P., Curci, G., Visconti, G., Bessagnet, B., Menut, L., and Park, R. J.: Modeling of gas and aerosol with WRF/Chem over Europe: Evaluation and sensitivity study, Journal of Geophysical Research: Atmospheres, 117, 10.1029/2011jd016302, 2012.

Vignati, E., Wilson, J., and Stier, P.: M7: An efficient size-resolved aerosol microphysics module for largescale aerosol transport models, Journal of Geophysical Research: Atmospheres, 109, D22202, 10.1029/2003JD004485, 2004.

Wang, Q., Jacob, D. J., Spackman, J. R., Perring, A. E., Schwarz, J. P., Moteki, N., Marais, E. A., Ge, C., Wang, J., and Barrett, S. R. H.: Global budget and radiative forcing of black carbon aerosol: Constraints from pole-to-pole (HIPPO) observations across the Pacific, Journal of Geophysical Research: Atmospheres, 119, 195-206, 10.1002/2013JD020824, 2014.

Wexler, A. S., and Clegg, S. L.: Atmospheric aerosol models for systems including the ions $\mathrm{H}+, \mathrm{NH} 4+, \mathrm{Na}^{+}$, SO42-, NO3-, Cl-, Br-, and H2O, Journal of Geophysical Research: Atmospheres, 107, 4207, doi:10.1029/2001JD000451, 2002.

Wiedinmyer, C., Akagi, S. K., Yokelson, R. J., Emmons, L. K., Al-Saadi, J. A., Orlando, J. J., and Soja, A. J.: The Fire INventory from NCAR (FINN): a high resolution global model to estimate the emissions from open burning, Geosci. Model Dev., 4, 625-641, 10.5194/gmd-4-625-2011, 2011.

$\mathrm{Xu}, \mathrm{L}$., and Penner, J. E.: Global simulations of nitrate and ammonium aerosols and their radiative effects, Atmos. Chem. Phys., 12, 9479-9504, 10.5194/acp-12-9479-2012, 2012.

Yu, F., and Luo, G.: Simulation of particle size distribution with a global aerosol model: contribution of nucleation to aerosol and CCN number concentrations, Atmos. Chem. Phys., 9, 7691-7710, 10.5194/acp-9-7691-2009, 2009.

Zaveri, R. A., Easter, R. C., Fast, J. D., and Peters, L. K.: Model for Simulating Aerosol Interactions and Chemistry (MOSAIC), Journal of Geophysical Research: Atmospheres, 113, 10.1029/2007JD008782, 2008. 